\title{
Monitoring benthic foraminiferal dynamics at Bottsand coastal lagoon (western Baltic Sea)
}

\author{
Joachim Schönfeld \\ Research Division Ocean Circulation and Climate Dynamics, GEOMAR Helmholtz Centre for Ocean Research \\ Kiel, Wischhofstrasse 1-3, 24148 Kiel, Germany \\ Correspondence: Joachim Schönfeld (jschoenfeld@geomar.de)
}

Received: 11 January 2018 - Revised: 11 April 2018 - Accepted: 16 April 2018 - Published: 24 April 2018

\begin{abstract}
Benthic foraminifera from Bottsand coastal lagoon, western Baltic Sea, have been studied since the mid-1960s. They were monitored annually in late autumn since 2003 at the terminal ditch of the lagoon. There were 12 different species recognised, of which three have not been recorded during earlier investigations. Dominant species showed strong interannual fluctuations and a steady increase in population densities over the last decade. Elphidium incertum, a stenohaline species of the Baltic deep water fauna, colonised the Bottsand lagoon in 2016, most likely during a period of salinities $>19$ units and water temperatures of $18^{\circ} \mathrm{C}$ on average in early autumn. The high salinities probably triggered their germination from a propagule bank in the ditch bottom sediment. The new E. incertum population showed densities higher by an order of magnitude than those of the indigenous species. The latter did not decline, revealing that $E$. incertum used another food source or occupied a different microhabitat. Elphidium incertum survived transient periods of lower salinities in late autumn 2017, though with reduced abundances, and became a regular faunal constituent at the Bottsand lagoon.
\end{abstract}

\section{Introduction}

Benthic foraminifera are reliable indicators for environmental conditions at the sea floor and general ecosystem status. In the course of ongoing global warming, environmental changes are expected to profoundly change the assemblage structure of near-shore foraminiferal communities (Haynert et al., 2011; Uthicke et al., 2013; Weinmann and Goldstein, 2016). This has only been recorded in extreme settings to date (Arieli et al., 2011; Schmid et al., 2015). Consequently, the benthic foraminiferal assemblage composition in a given area has been considered as rather static (e.g. Sen Gupta and Smith, 2010). Species' distribution areas are framed by their limiting ecological conditions (e.g. Schönfeld and Altenbach, 2005; Schönfeld, 2006), even though marked abundance fluctuations may occur due to seasonal variations in food supply or transient environmental deteriorations (e.g. Alve, 1995; Ogha and Kitazato, 1997; Schönfeld and Numberger, 2007). Strong currents, storm surges, turbidites, or drifting sea ice were invoked as the mechanisms of species dispersal beyond these ecological boundaries (Murray et al., 1982; Dieckmann et al., 1987; Lin et al., 2005;
Bolliet et al., 2014), whereas only a very few foraminiferal species have been displaced by human activities (McGann et al., 2000; Asteman and Schönfeld, 2016). This static concept of foraminiferal distribution has been challenged by the discovery of foraminiferal propagules (Alve and Goldstein, 2002 ), i.e. unilocular sexually or asexually produced juveniles, which are on the move and have not yet commenced with growth and chamber formation (Alve and Goldstein, 2003).

Several experiments have been performed to identify and incubate propagules from the $<32$ or $<63 \mu \mathrm{m}$ grain size fraction of surface sediments (Alve and Goldstein, 2003, 2010; Goldstein and Alve, 2011; Weinmann and Goldstein, 2017). Surprisingly, only shallow water foraminifera could be raised from propagule associations of deep fjord and shelf samples. Some had never been found living close to the sampling site, and faunas with different compositions grew under the different conditions. The experimental results indicated a wide dispersal and mixing of propagules by ocean or tidal currents. They accumulate in surface sediments, and only those species whose preferred conditions develop will mature. The 
environmental triggers for their growth and the resilience of the juveniles are not well constrained to date.

In this short note, a sudden bloom of the stenohaline $\mathrm{El}$ phidium incertum in a low-saline, shallow water lagoon from the Baltic Sea is reported. Hydrographic monitoring data at the sampling site displayed a short period of exceptionally high salinities of 19.8 units on average 2 months before. The population has successfully recruited and could stand conditions at its ecological limits for more than 1 year. These findings provide compelling evidence for the powerful potential of propagules: they are waiting in the wings to restructure near-shore foraminiferal faunas in case of profound environmental changes.

\subsection{Geographical and environmental setting}

The nature reserve Bottsand is situated at the western Baltic coast of Germany, about $20 \mathrm{~km}$ to the northeast of Kiel (Fig. 1). The lagoon is confined to the south by the Wendtorf Marina and to the east by a dike that has been built in 18801882 and was refurbished in 1982. The northern fringe is a $1.4 \mathrm{~km}$ long spit bar. The successive westward progradation of the spit since 1870 has effected an almost complete closure of the lagoon (Schrader, 1990; Knief, 2013). Bogs grew through aggradation at the northern margin of the lagoon, where an extensive salt marsh developed (Wolfram, 1996). A concomitant aggradation of the salt marsh at the foot of the dike has tapered the lagoon to a terminal ditch that runs out in a series of ponds. The northern part of the lagoon is separated from the southern part by a broad shoal that falls dry at low water.

The bottom sediment of the lagoon is a fine to medium sand (Grabert, 1971). The sediment surface is covered by a few centimetres of rotted plant debris in places (Lehmann, 2000). The invertebrate fauna of Bottsand is characterised by dense lugworm colonies and clusters of Mytilus edulis and other molluscs that are common in the Baltic Sea. The plant associations are dominated by macroalgae (Fucus vesiculosus, Zostera marina) (Hammann and Zimmer, 2014). In marginal areas of the lagoon, where the water is only a few centimetres deep, patches of sea rush and saltwort (Bolboschoenus maritimus, Salicornia stricta) are found.

The salinity of lagoonal waters varied between 12 and 18 units. It was markedly lower in the terminal northeastern ditch at 6 to 10 salinity units, mainly due to precipitation and ground water seeping (Lutze, 1968a). The water temperatures in the lagoon were mostly 4 to $5^{\circ} \mathrm{C}$ higher than the surface water temperature of the adjacent Baltic Sea. A significant environmental parameter for the ecosystems in the lagoon is water level changes, which are driven by wind direction change (Sztobryn et al., 2009). Onshore winds may raise the water level up to $2 \mathrm{~m}$, in extreme cases even to $3 \mathrm{~m}$ above standard German reference level (NN), and they may fall to $1.5 \mathrm{~m}$ below NN in Kiel Bight (Härdtle, 1984). The tidal range is rather low, at approximately $\pm 0.10 \mathrm{~m}$.

\subsection{Foraminiferal assemblages}

The foraminifera from the Bottsand lagoon and the adjoining salt marsh have been studied since the mid-1960s. Early surveys focused on the general distribution of foraminiferal species in the lagoon and Baltic Sea, as well as their growth, reproduction (Lutze, 1968a), and patchiness (Lutze, 1968b) and the redeposition of tests (Grabert, 1971). The faunal inventory, microenvironments, and reproductive cycles of salt marsh foraminifera were described (Brönnimann et al., 1989; Lehmann, 2000; Lehmann et al., 2006). These studies revealed that the lagoon was populated by four species, of which Elphidium williamsoni was the only rotaliid. The highest population densities were recorded at a two-step brink separating the salt marsh from the lagoon. Miliammina fusca, Ammotium salsum, and Trochamminids were frequent here. The salt marsh fauna was dominated by Trochammina inflata, Haplophragmoides manilaensis, Miliammina fusca, and Tiphotrocha comprimata. Balticammina pseudomacrescens was found at the brink and in the distal Festuca lawn.

The annual monitoring of the foraminiferal fauna at the Bottsand lagoon was initiated in 2003. The aim of the project is to create a complement to the Boknis Eck time series (Bange et al., 2011) because the Bottsand lagoon and the adjacent salt marsh are influenced by both surface water dynamics of the Baltic Sea and predominant seasonal weather conditions. As in any other long-term study, the present investigation is driven by a null hypothesis, i.e. the foraminiferal fauna has not changed with reference to last year or to the last survey.

\section{Material and methods}

Samples have been taken annually since 2003 in midto late November at our monitoring site at $54^{\circ} 25.613^{\prime} \mathrm{N}$, $10^{\circ} 17.692^{\prime} \mathrm{E}$, close to sample 107 of Lutze (1968a) and P5 of Lehmann (2000). Additional samples from September, October, and December 2017 were also considered (Table 1). The samples were taken from the bottom of the terminal ditch within reach from the vegetation boundary, i.e. 0.4 to $1.0 \mathrm{~m}$ east of the brink.

A chamfered polycarbonate cylinder of 54 or $56 \mathrm{~mm}$ inner diameter was used. A graduated plastic ring and spatule were used to slice off the uppermost $1 \mathrm{~cm}$ of the surface sediment (Schönfeld et al., 2012). Analysing the 0$1 \mathrm{~cm}$ level was common practice in foraminiferal surveys in the Baltic Sea (e.g. Lutze, 1965; Schönfeld and Numberger, 2007; Polovodova et al., 2009; Frenzel et al., 2009). At Bottsand, the uppermost $5 \mathrm{~cm}$ were sampled in 19641967 (Lutze, 1968a), and the $0-1 \mathrm{~cm}$ interval was sampled in 1996-1998 (Lehmann, 2000).

The samples of the present study were transferred into $200 \mathrm{~mL}$ PVC (Kautex ${ }^{\circledR}$ ) bottles, preserved, and stained with a Rose Bengal ethanol solution $\left(2 \mathrm{gL}^{-1}\right)$. The sample vol- 

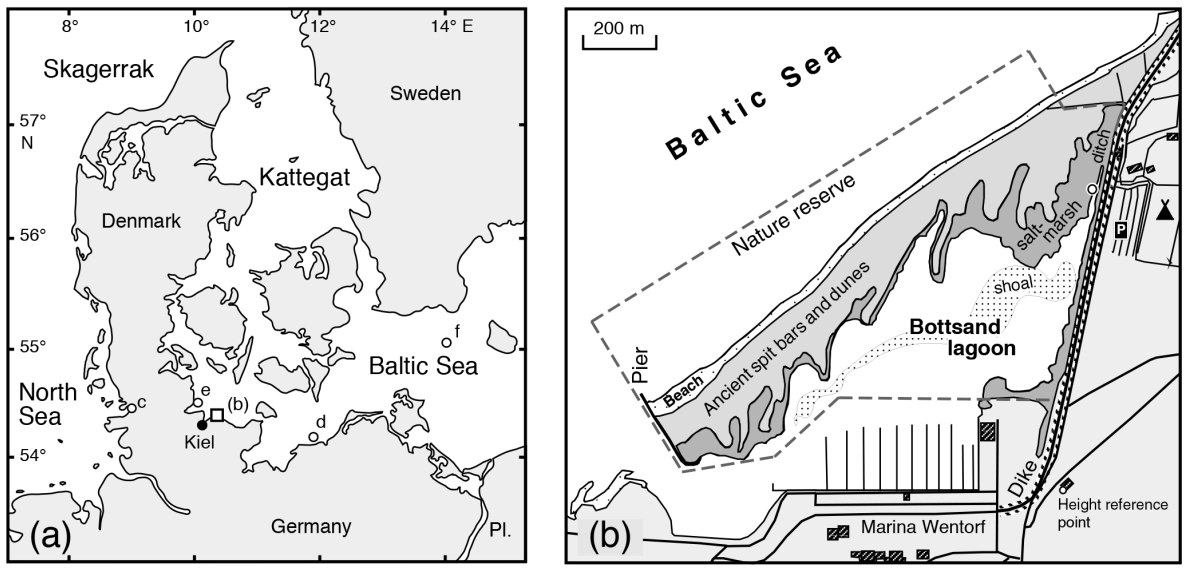

Figure 1. Geographical overview (a) and location map (b) of the Bottsand lagoon. Circle: monitoring station in the terminal ditch. Other sampling locations: (c) tidal flats at Schobüll (Lehmann, 2000); (d) Wismar Bight (Frenzel et al., 2009); (e) Boknis Eck (Schönfeld and Numberger, 2007); (f) Arkona Basin (Lutze, 1965). The demarcation of the Baltic Sea, Kattegat, and Skagerrak is applied according to the definition of the International Hydrographic Organisation (IHO, 1953).

ume was marked on the bottle immediately after sampling. Temperature and salinity of lagoonal water were measured after sampling with WTW LF 320 and Cond 3210 conductimeters equipped with a TetraCon 325 probe. The conductimeters had a precision of $<0.5 \%$ of measured conductivity and $<0.1 \mathrm{~K}$ according to a manufacturer's test certificate. The hand-held instruments were calibrated using either a 3.24356 weight percent potassium chloride solution with a conductivity of $53 \mathrm{mS} \mathrm{cm}^{-1}$ at $15^{\circ} \mathrm{C}$, referring to a salinity of 35 practical salinity units (psu) according to the PSS78 scale (Culkin and Smith, 1980; Millero, 1993), or substandards of seawater measured with a high-precision thermosalinograph that has been calibrated with IAPSO Standard Seawater with a $19.37394 \mathrm{ppt} \mathrm{Cl}^{-}$concentration, i.e. $35 \mathrm{~g} \mathrm{~kg}^{-1}$ (\%o) solutes. As both modes of instrument calibration were used in the present study, the salinity is denominated with the dimensionless term "unit". The sample heights were determined with a Zeiss Ni2 (2003-2011) and Leica NA728 (20122017) surveyor's level. The levels were tied to a geodetic reference point at the building at Schleusenweg $2(1.350 \mathrm{~m} \mathrm{NN}$; Fig. 1). The accuracy of levelling is $< \pm 0.5 \mathrm{~cm}$.

Since 2012, temperature and salinity, and since 2013 also the water level of the lagoon was measured close to the sampling site at $20 \mathrm{~min}$ intervals with Odyssey pressuretemperature and conductivity-temperature recorders for periods ranging from 49 to 79 days before sampling (Table 1). Their precision was $\pm 0.1 \%$ for pressure, $\pm 3 \%$ for conductivity, and $\pm 1{ }^{\circ} \mathrm{C}$ for temperature according to the manufacturer's data sheets. The accuracy after calibration with standard solutions was $\pm 0.29 \mathrm{~cm}$ for immersion depth, \pm 0.18 salinity units, and $\pm 0.23{ }^{\circ} \mathrm{C}$ ( $1 \sigma$ values). The external reproducibility was $\pm 1 \mathrm{~cm}$ immersion depth, \pm 0.3 salinity units, and $\pm 0.5^{\circ} \mathrm{C}$ ( $1 \sigma$ values), as depicted by a comparison of logger records and on-site measurements with the WTW con- ductimeters. Water level records of Kiel Fjord measured at the Holtenau locks tide gauge were obtained from online resources (raw data; http://www.pegelonline.wsv.de, last access: 22 April 2018).

The foraminiferal samples were left in the Rose Bengal ethanol solution for at least 2 weeks in order to achieve a pervasive cytoplasm staining of specimens that were living at the time of sampling (Lutze and Altenbach, 1991). Thereafter, the samples were prepared and picked by the author following the procedures described by Schönfeld et al. $(2012,2013)$ and Lübbers and Schönfeld (2018). Only well-stained specimens from the living fauna were considered in this study. They were sorted by species in Plummer cell slides, fixed with glue, and counted. Images for species' documentation were taken with a Keyence VHX-700 FD digital microscope at the Institute of Geosciences, Kiel University. Faunal indices were calculated with Past v3.16 (Hammer et al., 2001), frequency analyses of water level records were performed with AnalySeries v1.2 (Paillard et al., 1996). All dates and times are given in Central European Time (MEZ), i.e. Greenwich Mean Time $+1 \mathrm{~h}$.

\section{Results}

\subsection{Hydrography}

The Bottsand lagoon water levels showed a low-amplitude daily variability of $0.1-0.3 \mathrm{~m}$ and occasionally high waters of $0.6-1.0 \mathrm{~m} \mathrm{NN}$ lasting several days. Water levels below $0.01 \mathrm{~m} \mathrm{NN}$ were generally not recorded, resembling an average minimum water depth of $0.1 \mathrm{~m}$ close to our sampling site. Hence the terminal ditch of the lagoon never fell dry, which is in agreement with personal observations by the author on unnumbered visits to the area. Corresponding tide gauge records from Kiel Fjord documented low water levels 


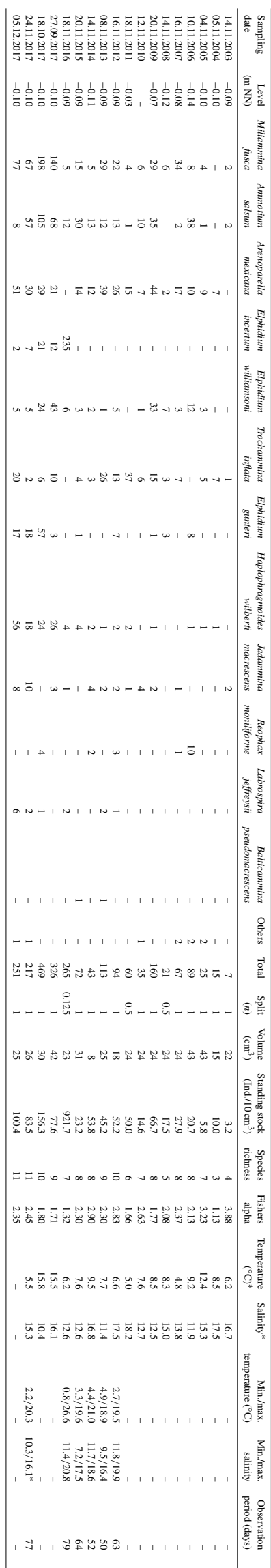

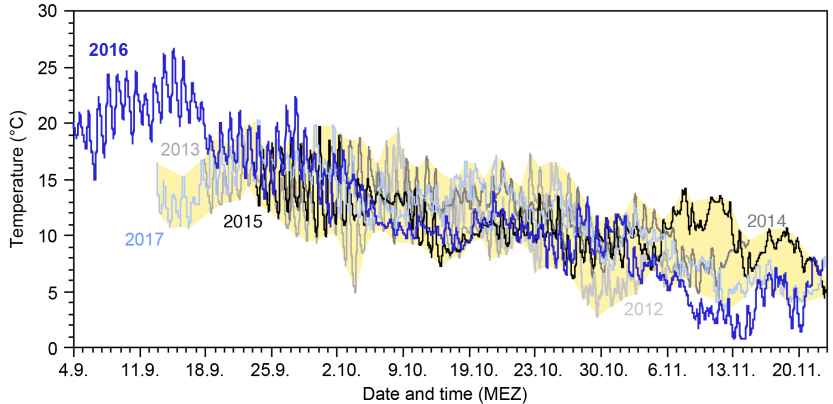
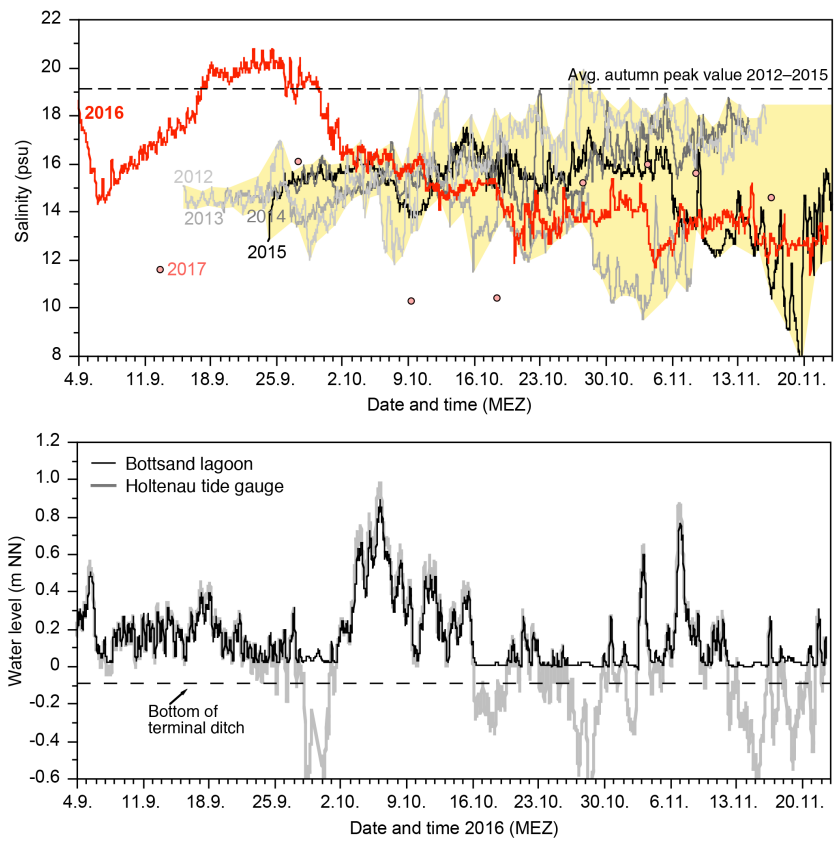

Figure 2. Temperature, salinity, and 2016 water level records from the monitoring site at the Bottsand lagoon and Holtenau tide gauge (raw data). The yellow polygon envelops the data range of 2012 through 2015 and 2017 logging records (Schönfeld, 2018).

of $-0.75 \mathrm{~m} \mathrm{NN}$ or even less during our measuring periods in 2012 through 2017 (Fig. 2).

The temperature showed a successive decline of water temperatures from $18^{\circ} \mathrm{C}$ in mid-September to ca. $7^{\circ} \mathrm{C}$ on average in mid-November 2012 through 2016 . The diurnal variability was rather high in September, with $5-7^{\circ} \mathrm{C}$, whereas it was only $2-3^{\circ} \mathrm{C}$ in November. The records of the different years matched well during September and October but fanned out with the beginning of November (Fig. 2).

The salinities showed a much stronger and irregular variability than the temperatures. The inter- and intra-annual salinity variability was low during September in 2012 at 2 to 3 units compared to 2015. Strong oscillations with amplitudes of up to 7 salinity units commenced with the beginning of October during these years. The records of the individual years spread apart by the end of October, effecting a variability between a minimum of 8 and average maximum values of 19 salinity units among the years 2012 to 2015 . The salinity 


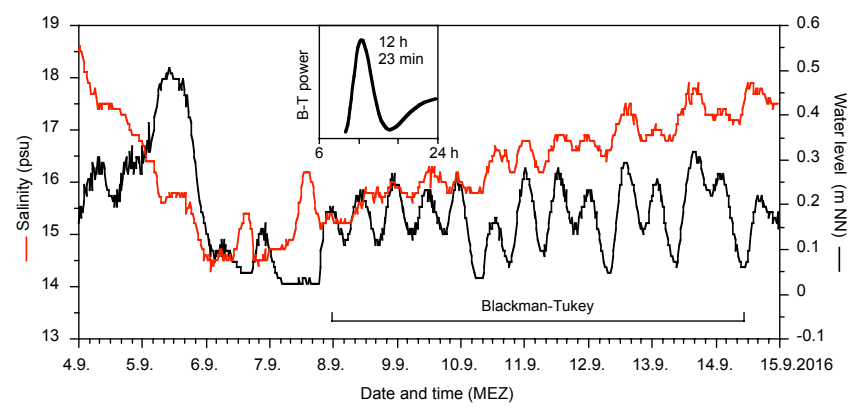

Figure 3. Time series of rising salinities and fluctuating water level in the terminal ditch of the Bottsand lagoon driven by the M2 tidal cycle.

curve of 2016, however, showed a broad, extraordinary maximum at which salinities exceeded the average autumn peak value for a period of 13 days. The 2016 curve merged with the salinity records from 2012 to 2015 no earlier than at the beginning of October. The salinity sensor of the data logger failed in 2017 but on-site measurements showed markedly lower values of 10-16 salinity units in September and early October.

A striking coherence of transient, short-term water level and salinity maxima was recognised at the beginning of the salinity rise in September 2016, following the lunar semidiurnal M2 tidal constituent of $12 \mathrm{~h}$ and $25 \mathrm{~min}$. The northern part of the lagoon was thereby flushed with salt-rich water during every flood, which was, however, diluted again only in part during the next low tide, probably by less-saline ground water seeping (Fig. 3).

\subsection{Foraminiferal distribution}

There were 12 foraminiferal species recorded in the present study. They comprise nine arenaceous species and three calcareous species of the genus Elphidium (Table 1). Miliammina fusca, Ammotium salsum, Elphidium williamsoni, and Trochammina inflata were common to frequent with proportions varying between 1 and $57 \%$ of the living fauna, even though individual species were occasionally not found (Fig. 4). Arenoparella mexicana depicted more constant proportions ranging from 6 to $47 \%$, mostly varying between 10 and $36 \%$. All these species have been found in lagoonal or terminal ditch faunas in 1966 and 1996 as well (Lutze, 1968a; Lehmann, 2000). The proportions of Miliammina fusca and Elphidium williamsoni were much higher in the 1960s than in the early 2000s. Elphidium incertum suddenly appeared in 2016 and made up $89 \%$ of the entire fauna, thereby outnumbering all other species. It returned to much lower proportions in 2017. E. incertum has not been found in the lagoon before. In total, the six ranked species comprise on average $87.4 \%$ of the living fauna.

Among the rare species, Elphidium gunteri and Reophax moniliforme had also not been recorded in the Bottsand la-

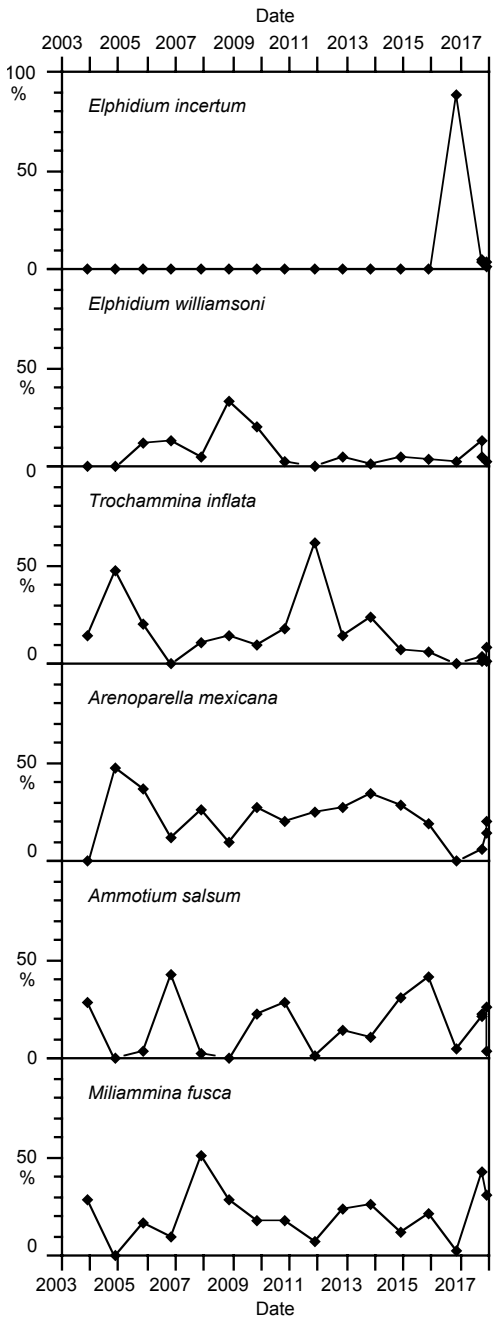

Figure 4. Proportions of the six ranked species at the monitoring site at the Bottsand lagoon.

goon before 2003. They recurrently showed up during certain years since then and were, with two exceptions, not found again in the following year. A similar stochastic occurrence pattern is recognised in Labrospira jeffreysii.

The foraminiferal population densities varied between 3 and 67 specimens per $10 \mathrm{~cm}^{3}$ surface sediment, and they steadily increased during the years 2003 to 2015 . The population densities suddenly increased to 922 specimens per $10 \mathrm{~cm}^{3}$ in 2016, of which E. incertum accounted for 817 specimens; the afore-mentioned trend continued for the other species (Fig. 5). The standing stock of E. incertum returned to 3 and 7 specimens per $10 \mathrm{~cm}^{3}$ in 2017 , levels that compare well to other, less frequent species in these samples. The Fisher's alpha diversity index ranged from 1.1 to 3.9 and mostly varied around 2 , a value that is common for marginal marine foraminiferal assemblages (Table 1). 


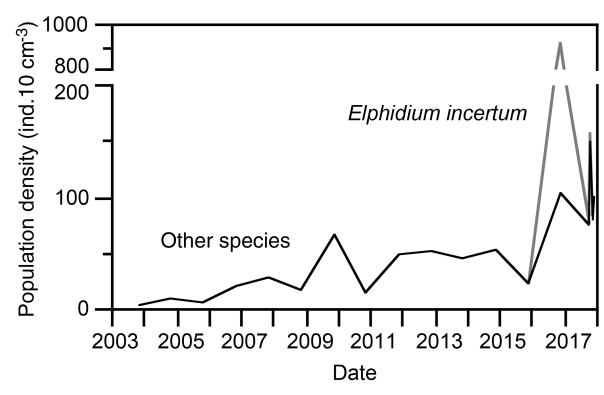

Figure 5. Population density of the living foraminiferal fauna and Elphidium incertum. Note the scale break on the $y$ axis.

\section{Discussion}

\subsection{Faunal composition}

A long-term assessment of the benthic foraminiferal faunas of the Bottsand lagoon is hampered by the fact that the previous studies focused on different locations and used a different methodology. In 1966, the lagoonal bottom was inhabited by Elphidium williamsoni (Cribrononion articulatum of authors) and Miliammina fusca only, both showing profound seasonal variations. At the vegetation boundary or in the terminal ditch of the lagoon, Ammotium salsum, Jadammina macrescens, Trochammina inflata, Tiphotrocha comprimata, and Haplophragmoides wilberti ( $H$. bonplandi of authors) were common to frequent (Lutze, 1968a). In 1996, Ammotium salsum spread and populated the entire lagoon and Ovammina opaca was frequent as well (Lehmann, 2000). The latter species may not have been recognised because the samples were picked dry in the 1960s. However, the bottom of the terminal ditch was not sampled in 1996 but the brink before the vegetation boundary was. Balticammina pseudomacrescens, Psammosphaera sp., and Arenoparella mexicana were recorded here as well and showed a small-scale lateral variability. The latter two species were not found in 1966, and Ammotium salsum was missing here in 1996. The trend of increasing species richness continued in the early 2000s as described above, in particular with the recurrent recruitment of two more Elphidium species, Elphidium incertum, and the repopulation of the terminal ditch by Ammotium salsum. However, the interannual fluctuations of dominant species' proportions and population densities showed no coherence with meteorological records, as for instance seasonal or annual average temperatures or sunshine hours. The conclusion of Lutze (1968a), that these parameters exerted a positive influence on the faunas, is therefore not corroborated by the data from this study. The overall trend of increasing species richness and the interannual variation in species' abundances may not be related to changes in substrate properties because the surface sediment was always a crumbly to semi-fluid, organic-rich, sandy mud at the monitoring site.

\subsection{Recognition of Elphidium incertum}

Elphidium incertum is commonly found in boreal to arctic seas of Europe where it occurs in intertidal to subtidal environments around the British Isles and in marginal seas and fjords below the halocline (e.g. Horton and Edwards, 2006; Polyak et al., 2002; Nordberg et al., 2017). The salinities prevailing at the sampling sites on British intertidal flats were open marine, and they were not lower than 25 units in the southern Kara Sea, which assigns E. incertum as a stenohaline organism (Darling et al., 2016). In the western Baltic Sea, however, E. incertum was dwelling in sandy muds at depths between 16 and $25 \mathrm{~m}$ that were bathed by inflowing Kattegat water of 20 to 24 salinity units (Lutze, 1974; Schönfeld and Numberger, 2007; Polovodova et al., 2009). The species has only been occasionally recorded at depths shallower than $13 \mathrm{~m}$, and at presumably even lower salinities, thus challenging the above-mentioned threshold value.

The microhabitat of E. incertum is shallow endobenthic. It lives underneath the immediate sediment surface and above the redox boundary (Wefer, 1976). The abundance maximum is centred in the uppermost $5-6 \mathrm{~mm}$ of the oxidised nearsurface layer (Lutze, 1974). The species was found at the sediment surface only when the redox boundary had moved upwards during hypoxic periods (Wefer, 1976). Therefore, and even under pore water deoxygenation, the $E$. incertum abundance maximum was entirely covered by the $0-1 \mathrm{~cm}$ sample interval at the Bottsand monitoring site.

The size of E. incertum from the Baltic Sea was ca. 600 to $800 \mu \mathrm{m}$, whereas specimens from the Bottsand lagoon were only ca. 125 to $250 \mu \mathrm{m}$ in diameter and thus much smaller (Plate 1). Populations of E. incertum with consistently smaller specimens of 350 to $550 \mu \mathrm{m}$ test diameter were described from the margins of the Bornholm and Gotland basins in the central Baltic and denominated as Cribrononion incertum subsp. A by Lutze (1965). The chambers were slightly inflated and the umbilicus was depressed and covered with small pustules (Plate 1). Morphotypes with a similar size $(360 \mu \mathrm{m})$ have been recorded from $19 \mathrm{~m}$ water depth at Wismar Bight, southern Baltic Sea (Frenzel et al., 2009), and were identified as Haynesina germanica. The specimens from Bottsand, however, were lacking diagnostic features of H. germanica, in particular the collar of pustules at the base of the apertural face of the last chamber (Austin et al., 2005), the smooth, transparent chamber wall, the widened sutures close to the umbilicus, and the tendency of evolute, oblique coiling. Instead, their chambers are slightly inflated and the outline is lobate (Plate 1). These features are also characteristic for the subarctic Haynesina orbicularis or the smallsized Elphidium albiumbilicatum. The latter is common in the Baltic Sea as well. However, the field of pustules densely covering the umbilicus is quite large compared to the individuals from Bottsand and extends on the flanks of both sides of the sutures, whereas pustules follow a thin seam along both sides of the narrow incised sutures of the Bottsand speci- 


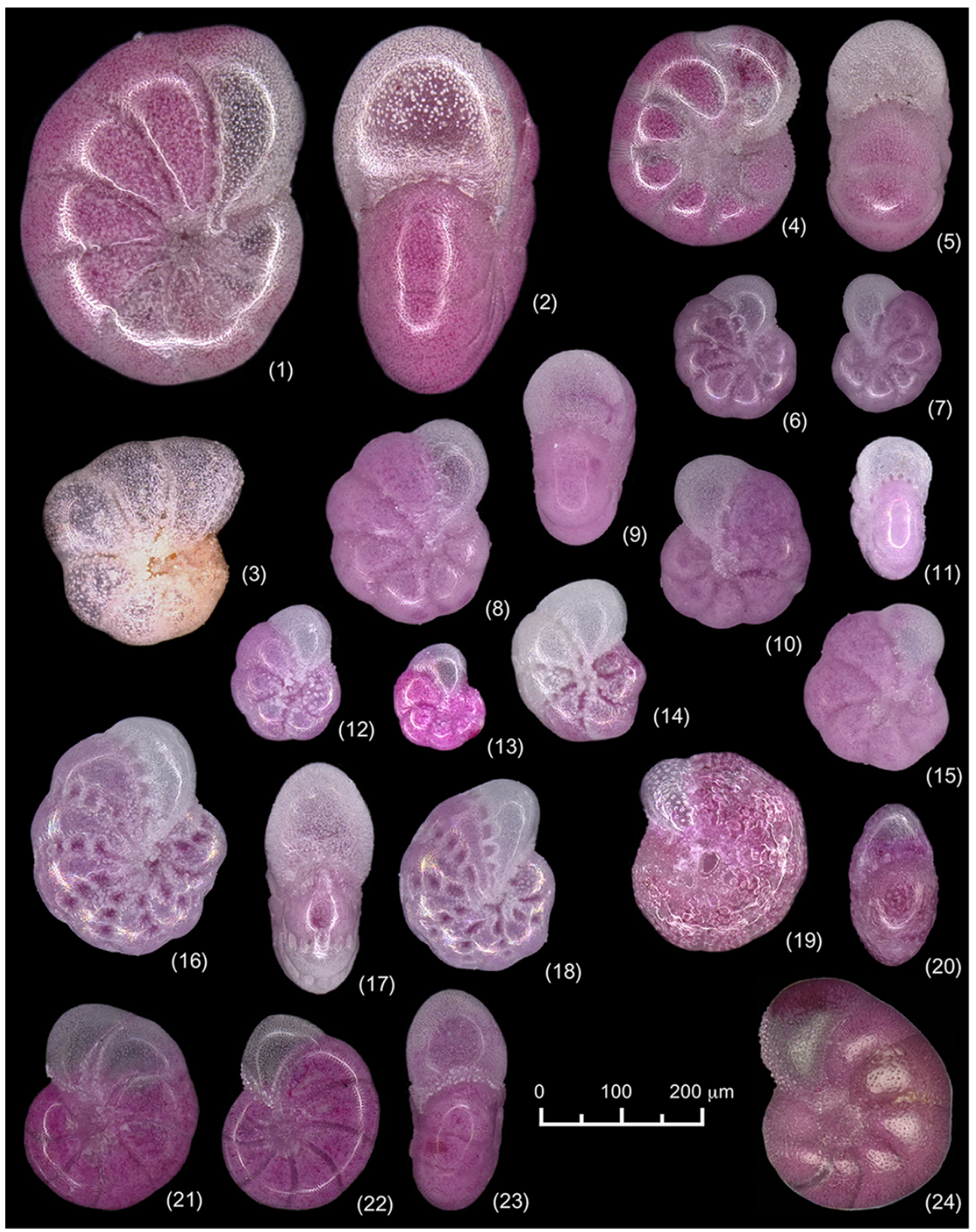

Plate 1. Light microscopic images of the Elphidium species discussed in this paper. (1-2) Elphidium incertum, (4, 5) Elphidium albiumbilicatum, both species from Boknis Eck, $23.5 \mathrm{~m}$ water depth (Schönfeld and Numberger, 2007; their station PF13); (3) Elphidium incertum subsp. A, Gerhard-Friedrich Lutze collection, Arkona Basin, 43 m water depth (Lutze, 1965; his station 72); (6-15) Elphidium incertum, (16-18) Elphidium williamsoni, and $(\mathbf{1 9}, \mathbf{2 0})$ Elphidium gunteri, all specimens from the Bottsand lagoon, monitoring site in the terminal ditch (this study); (21-23) Haynesina germanica, tidal flats at Schobüll; (24) Haynesina orbicularis, salt marsh at Borgarnes, Iceland (image courtesy of Julia Lübbers, Kiel).

mens. The pustules merge, thicken, and form one to three bundles bridging the sutures between later chambers, which is a diagnostic feature discriminating $E$. incertum from other Elphidium species (Lutze, 1965). Finally, a small, lobate $E$. incertum with a pustulous umbilicus from the Kara Sea has been described, where it is common in estuarine settings under the influence of major rivers (Polyak et al., 2002). The occurrences from Bottsand, Wismar Bight, and the central Baltic provide corroborating evidence and suggest that this morphotype has to be considered as an ecophenotype rather than as a subspecies or even a different taxon. 


\subsection{Propagule trajectories and environmental constraints}

Bottsand is a nature reserve and strictly closed to human activities like fisheries or ship traffic that could convey alien species to this area. However, the lagoon is flushed by sporadically high waters, often associated with strong northerly gales, which may well have stirred up foraminiferal propagules by deep, grounding waves and carried them into the lagoon in suspension. This has probably happened more than once a year since the late 19th century, when the lagoon started to form (Schrader, 1990). The question remains of why E. incertum or other Baltic deep water taxa have never been found at the Bottsand lagoon before even though hundreds of samples were examined since the 1960s. The salinity records provide a persuasive explanation: values of more than 19.9 units have never been recorded (Table 1). They were created in early September 2016 by enhanced evaporation due the high temperatures and regular inflows from the adjacent Baltic Sea during high tides, which effected, in combination, a successive salt concentration in the terminal ditch (Fig. 3). It is conceivable that a period of 13 days around the lower salinity limit of this species and high temperatures could have triggered the propagules to grow.

One may argue that $E$. incertum had already occurred earlier, that the tests were not preserved, and the species had therefore been missed. Indeed, only a few, corroded $E$. williamsoni specimens were observed among the unstained tests in the samples, which were not systematically investigated in the present study. Nonetheless, Lutze (1974) noted that $E$. incertum was less frequent in the dead assemblage compared to its proportion of the living fauna in Kiel Bight. The turnover rate and test production was considered to be substantially lower than in other species. If this is applicable to the Bottsand lagoon too, a sporadic occurrence of a few living specimens between 1996 and 2003 would hardly have left any record in the surface sediments.

The infaunal $E$. incertum requires high concentrations of food particles, even though it is not strictly bloom feeding, and it is less tolerant to extended hypoxic conditions (Gustafsson and Nordberg, 1999; Polovodova et al., 2009). Both preconditions are given in the organic detritus surface layer and shallow water depth of the ditch. As such, the population dynamics with a huge increase in standing stock was similar to any other first colonising invasive species, even though the constant population densities of the other species suggest that $E$. incertum either used a different food source or microhabitat than the other, indigenous foraminiferal species, or that the carrying capacity of the habitat has not been used at all. The fact that the diversity did not decline substantially with the bloom of the newcomer corroborates this conclusion (Fig. 5). Furthermore, the faunal data suggested a high resilience of E. incertum to periods of low salinity as recorded in late 2017 . Whether the species will continue to survive in the coming years remains to be tested by continuing the monitoring programme.

\section{Conclusions}

The long-term dynamics of benthic foraminiferal faunas at the Bottsand lagoon is characterised by a successive increase in species richness and population densities, even though the pattern is superimposed by a strong seasonal, inter-annual, or lateral variability, which is not yet completely understood. Elphidium incertum, a foraminiferal species dwelling in the open Baltic Sea at depth, successfully colonised the Bottsand lagoon in early autumn 2016 . This happened most likely during a short period of extraordinary high salinities and warm water temperatures. In particular, a salinity of $>19$ units lasting for several days was seemingly necessary. The lower salinity limit of E. incertum is therefore constrained to 1920 units, substantially lower than suggested before (Darling et al., 2016). It is conceivable that the above-mentioned environmental setting has triggered the germination from a rich propagule bank, which is sustained by flushing of the lagoon in the course of rising water levels. If so, the observed pattern would corroborate evidence from Doboy Sound, Georgia, USA, for a predominantly landward-directed transport of propagules in marginal marine environments (Weinmann and Goldstein, 2017). The newly raised E. incertum population encountered ideal living conditions, responded with a bloom and reached population densities 1 order of magnitude higher than those of the indigenous species. Neither their standing stock nor the diversity of the entire foraminiferal fauna declined substantially, thus indicating that $E$. incertum used another food source or occupied a different microhabitat than the indigenous foraminifera. The new E. incertum population showed a remarkable resilience against transient periods of salinities lower than 16 units and was still there in late autumn 2017, though with standing stock values comparable to other species. As such, E. incertum became a regular faunal constituent in the terminal ditch of the Bottsand lagoon.

Data availability. The faunal census data analysed in this paper are available in Table 1. Temperature, salinity, and water level logging data are available in the PANGAEA database (Schönfeld, 2018; https://doi.org/10.1594/PANGAEA.884925). 


\section{Appendix A: Taxonomic list}

The list comprises all foraminiferal species mentioned in this paper in alphabetical order. The type references can be found in the Ellis and Messina (1940) catalogue. They are not included in the reference list.

Ammotium salsum (Cushman und Brönnimann 1948)

Arenoparella mexicana (Kornfeld 1931)

Balthicammina pseudomacrescens Brönnimann, Lutze und Whittaker 1989

Cribrononion articulatum (d'Orbigny 1839)

Elphidium albiumbilicatum (Weiss 1954)

Elphidium gunteri Cole 1931

Elphidium incertum (Williamson 1858)

Elphidium williamsoni Haynes 1973

Haplophragmoides bonplandi Todd and Brönnimann 1957

Haplophragmoides manilaensis Andersen 1953

Haplophragmoides wilberti Andersen 1953

Haynesina germanica (Ehrenberg 1839)

Haynesina orbicularis (Brady 1881)

Jadammina macrescens (Brady 1870)

Labrospira jeffreysii (Williamson 1858)

Miliammina fusca (Brady 1870)

Ovammina opaca Dahlgren 1962

Psammosphaera sp. Schulze 1875

Reophax moniliforme Siddall 1886,

Tiphotrocha comprimata (Cushman und Brönnimann 1948)

Trochammina inflata (Montagu 1808) 
Competing interests. The author declares that he has no conflict of interest.

Acknowledgements. Silvia Nordmann, lower Nature Conservation Authority of Plön District, and Carsten Harrje, NABU Schleswig-Holstein and warden-in-chief of Bottsand Nature Reserve, permitted access to the conservation area. Herwig Nöthel, Federal Waterways and Shipping Authority at Lübeck, gave clearance for the publication of raw data from the Holtenau tide gauge. Wolfgang Kuhnt, Anke Dettner-Schönfeld, Julia Lübbers, Jacek Raddatz, and students of the Master of Geoscience course "Foraminiferen im Schleswig-Holsteinischen Wattenmeer" at Kiel University helped during fieldwork. WK provided microscopic facilities and access to the Gerhard-Friedrich Lutze collection of Baltic Sea foraminifera at the Institute of Geosciences, Kiel University, and access to the Ellis and Messina Catalogue of Foraminifera, which is gratefully acknowledged. Kirsty Edgar, Marek Zajączkowski, and the anonymous reviewer are thanked for their comments and suggestions on an earlier version of this paper.

The article processing charges for this open-access

publication were covered by a Research

Centre of the Helmholtz Association.

Edited by: Kirsty Edgar

Reviewed by: Marek Zajączkowski and one anonymous referee

\section{References}

Alve, E.: Benthic foraminiferal distribution and recolonization of formerly anoxic environments in Drammensfjord, southern Norway, Mar. Micropaleontol., 25, 169-186, 1995.

Alve, E. and Goldstein, S. T.: Resting stage in benthic foraminiferal propagules: a key feature for dispersal? Evidence from two shallow-water species, J. Micropalaeontol., 21, 95-96, https://doi.org/10.1144/jm.21.1.95, 2002.

Alve, E. and Goldstein, S.: Propagule transport as key method of dispersal in benthic foraminifera (Protista), Limnol. Oceanogr., 48, 2163-2170, 2003.

Alve, E. and Goldstein, S. T.: Dispersal, survival and delayed growth of benthic foraminiferal propagules, J. Sea Res., 63, 3651, 2010.

Arieli, R. N., Almogi-Labin, A., Abramovich, S., and Herut, B.: The effect of thermal pollution on benthic foraminiferal assemblages in the Mediterranean shoreface adjacent to Hadera power plant (Israel), Mar. Pollut. Bull., 62, 1002-1012, 2011.

Asteman, I. P. and Schönfeld, J.: Recent invasion of the foraminifer Nonionella stella Cushman \& Moyer, 1930 in northern European waters: evidence from the Skagerrak and its fjords, J. Micropalaeontol., 35, 20-25, https://doi.org/10.1144/jmpaleo2015$007,2016$.

Austin, H. A., Austin, W. E. N., and Paterson, D. M.: Extracellular cracking and content removal of the benthic diatom Pleurosigma angulatum (Quekett) by the benthic foraminifera Haynesina germanica (Ehrenberg), Mar. Micropaleontol., 57, 68-73, 2005.

Bange, H. W., Hansen, H. P., Malien, F., Laß, K., Dale, A. W., Karstensen, J., Petereit, C., and Friedrichs, G.: Boknis Eck Time
Series Station (SW Baltic Sea): Measurements from 1957 to 2010, LOICZ Inprint, 2011, 16-22, 2011.

Bolliet, T., Jorissen, F. J., Schmidt, S., and Howa, H.: Benthic foraminifera from Capbreton Canyon revisited: faunal evolution after repetitive sediment disturbance, Deep-Sea Res. Pt. II, 104, 319-334, 2014.

Brönnimann, P., Lutze, G. F., and Whittaker, J. E.: Balticammina pseudomacrescens, a new brackish water trochamminid from the western Baltic sea, with remarks on the wall structure, Meyniana, 41, 167-177, 1989.

Culkin, F. and Smith, N. D.: Determination of the concentration of Potassium Chloride solution having the same electrical conductivity, at $15^{\circ} \mathrm{C}$ and infinite frequency, as Standard Seawater of Salinity $35.0000 \%$ (Chlorinity $19.37394 \%$ ), IEEE J. Oceanic Eng., OE-5, 22-23, 1980.

Darling, K. F., Schweizer, M., Knudsen, K. L., Evans, K. M., Bird, C., Roberts, A., Filipsson, H. L., Kim, J.-H., Gudmundsson, G., Wade, C. M., Sayer, M. D. J., and Austin, W. E. N.: The genetic diversity, phylogeography and morphology of Elphidiidae (Foraminifera) in the Northeast Atlantic, Mar. Micropaleontol., 129, 1-23, 2016.

Dieckmann, G., Hemleben, C., and Spindler, M.: Biogenic and mineral inclusions in a green iceberg from the Weddell Sea, Antarctica, Polar Biol., 7, 31-33, 1987.

Ellis, B. F. and Messina, A.: Cataloque of foraminifera, Micropaleontology Press, New York, 1940.

Frenzel, P., Borrmann, C., Lauenburg, B., Bohling, B., and Bartholdy, J.: Environmental impact assessment of sediment dumping in the southern Baltic Sea using meiofaunal indicators, J. Mar. Syst., 75, 430-440, 2009.

Goldstein, S. T. and Alve, E.: Experimental assembly of foraminiferal communities from coastal propagule banks, Mar. Ecol.-Prog. Ser., 437, 1-11, 2011.

Grabert, B.: Zur Eignung von Foraminiferen als Indikatoren für Sandwanderung, Deutsche Hydrographische Zeitschrift, 24, 1$14,1971$.

Gustafsson, M. and Nordberg, K.: Benthic foraminifera and their response to hydrography, periodic hypoxic conditions and primary production in Koljö Fjord on the Swedish west coast, J. Sea Res., 41, 163-178, 1999.

Hammann, S. and Zimmer, M.: Wind-driven dynamics of beachcast wrack in a tide-free system, Open Journal of Marine Science, 4, 68-79, 2014.

Hammer, Ø., Harper, D. A. T., and Ryan, P. D.: PAST: Paleontological Statistics Software Package for Education and Data Analysis, Palaeontol. Electron., 4, 1-9, 2001.

Härdtle, W.: Vegetationskundliche Untersuchungen in Salzwiesen der ostholsteinischen Ostseeküste, Mitteilungen der Arbeitsgemeinschaft Geobotanik in Schleswig-Holstein und Hamburg, 34, 1-142, 1984.

Haynert, K., Schönfeld, J., Riebesell, U., and Polovodova, I.: Biometry and dissolution features of the benthic foraminifer Ammonia aomoriensis at high $p \mathrm{CO}_{2}$, Mar. Ecol.-Prog. Ser., 432, 53-67, 2011.

Horten, B. P. and Edwards, R. J.: Quantifying Holocene sea-level change using intertidal foraminiera: lessons from the British Isles, Cushman Foundation for Foraminiferal Research, Special Publication, 40, 1-97, 2006. 
International Hydrographic Organization (IHO): Limits of Oceans and Seas, Special Publication, 28, 1-39, 1953.

Knief, W.: Wiesenvogelmonitoring in Schleswig-Holstein: Ergebnisse einer einjährigen Brutvogelkartierung im NSG Barsbeker See und Umgebung/Probsteier Salzwiesen, Corax, 22, 293-301, 2013.

Lehmann, G.: Vorkommen, Populationsentwicklung, Ursache fleckenhafter Besiedlung und Fortpflanzungsbiologie von Foraminiferen in Salzwiesen und Flachwasser der Nord- und Ostseeküste Schleswig-Holsteins, Dissertation, ChristianAlbrechts-Universität Kiel, Germany, 218 pp., 2000.

Lehmann, G., Röttger, R., and Hohenegger, J.: Life cycle variation including trimorphism in the foraminifer Trochammina inflata from north European salt marshes, J. Foramin. Res., 36, 279290, 2006

Lin, H. L., Liu, J. T., and Hung, G. W.: Foraminiferal shells in sediment traps: Implications of biogenic particle transport in the Kao-ping submarine canyon, Taiwan, Cont. Shelf Res., 25, 2261-2272, 2005.

Lübbers, J. and Schönfeld, J.: Recent salt marsh foraminiferal assemblages from Iceland, Estuarine, Coastal and Shelf Science, 200, 380-394, 2018.

Lutze, G. F.: Zur Foraminiferen-Fauna der Ostsee, Meyniana, 15, 75-142, 1965.

Lutze, G. F.: Jahresgang der Foraminiferen-Fauna in der Bottsand Lagune (westliche Ostsee), Meyniana, 18, 13-30. 1968a.

Lutze, G. F.: Siedlungs-Strukturen rezenter Foraminiferen, Meyniana, 18, 31-34, 1968b.

Lutze, G. F.: Foraminiferen der Kieler Bucht (westliche Ostsee): 1. "Hausgartengebiet" des Sonderforschungsbereiches 95 der Universität Kiel, Meyniana, 26, 9-22, 1974.

Lutze, G.-F. and Altenbach, A.: Technik und Signifikanz der Lebendfärbung benthischer Foraminiferen mit Bengalrot, Geologisches Jahrbuch, A128, 251-265, 1991.

McGann, M., Sloan, D., and Cohen, A.: Invasion by a Japanese marine microorganism in western North America, Hydrobiologia, 421, 25-30, 2000.

Millero, F. J.: What is PSU?, Oceanography, 6, p. 67, 1993.

Murray, J. W., Sturrock, S., and Weston, J.: Suspended load transport of foraminiferal tests in a tide-and wave-swept sea, J. Foramin. Res., 12, 51-65, 1982.

Nordberg, K., Polovodova Asteman, I., Gallagher, T. M., and Robijn, A.: Recent oxygen depletion and benthic faunal change in shallow areas of Sanna's Fjord, Swedish west coast, J. Sea Res., 127, 46-62, 2017.

Ohga, T. and Kitazato, H.: Seasonal changes in bathyal foraminiferal populations in response to the flux of organic matter (Sagami Bay, Japan), Terra Nova, 9, 33-37, 1997.

Paillard, D., Labeyrie, L., and Yiou, P.: Macintosh program performs time-series analysis, EOS T. Am. Geophys. Un., 77, p. 379, 1996.

Polovodova, I., Nikulina, A., Schönfeld, J., and Dullo, W.C.: Recent benthic foraminifera in the Flensburg Fjord (Western Baltic Sea), J. Micropalaeontol., 28, 131-142, https://doi.org/10.1144/jm.28.2.131, 2009.

Polyak, L., Korsun, S., Febo, L. A., Stanovoy, V., Khusid, T., Hald, M., Paulsen, B. E., and Lubinski, D. J.: Benthic foraminiferal assemblages from the southern Kara Sea, a river-influenced Arctic marine environment, J. Foramin. Res., 32, 252-273, 2002.
Schmidt, C., Morard, R., Almogi-Labin, A., Weinmann, A. E., Titelboim, D., Abramovich, S., and Kucera, M.: Recent invasion of the symbiont-bearing foraminifera Pararotalia into the eastern Mediterranean facilitated by the ongoing warming trend, PLoS ONE, 10, e0132917, https://doi.org/10.1371/journal.pone.0132917, 2015.

Schönfeld, J.: Taxonomy and distribution of the Uvigerina peregrina plexus in the tropical to northeastern Atlantic, J. Foramin. Res., 36, 355-367, 2006.

Schönfeld, J.: Temperature, Salinity and water level recordings at Bottsand lagoon, western Baltic, 2012-2017, PANGAEA, https://doi.org/10.1594/PANGAEA.884925, 2018.

Schönfeld, J. and Altenbach, A. V.: Late glacial to Recent distribution pattern of deep-water Uvigerina species in the north-eastern Atlantic, Mar. Micropaleontol., 57, 1-24, 2005.

Schönfeld, J. and Numberger, L.: Seasonal dynamics and decadal changes of benthic foraminiferal assemblages in the western Baltic Sea (NW Europe), J. Micropalaeontol., 26, 47-60, https://doi.org/10.1144/jm.26.1.47, 2007.

Schönfeld, J., Alve, E., Geslin, E., Jorissen, F., Korsun, S., and Spezzaferri, S.: The FOBIMO (FOraminiferal BIo-Monitoring) initiative - Towards a standardised protocol for soft-bottom benthic foraminiferal monitoring studies, Mar. Micropaleontol., 9495, 1-13, 2012.

Schönfeld, J., Golikova, E., Korsun, S., and Spezzaferri, S.: The Helgoland Experiment - assessing the influence of methodologies on Recent benthic foraminiferal assemblage composition, J. Micropalaeontol., 32, 161-182, https://doi.org/10.1144/jmpaleo2012-022, 2013.

Schrader, E.: Dünengenese im Raume des Bottsandes - Kieler Außenförde, Schriften des Naturwissenschaftlichen Vereins Schleswig-Holstein, 60, 29-69, 1990.

Sen Gupta, B. K. and Smith, L. E.: Modern benthic foraminifera of the Gulf of Mexico: a census report, J. Foramin. Res., 40, 247265, 2010.

Sztobryn, M., Weidig, B., Stanislawczyk, I., Holfort, J., Kowalska, B., Mykita, M., Kanska, A., Krzysztofik, K., and Perlet, I.: Negative Surges in the Southern Baltic Sea (Western and Central Parts), Berichte des Bundesamtes für Seeschifffahrt und Hydrographie, 45, 1-71, 2009.

Uthicke, S., Momigliano, P., and Fabricius, K. E.: High risk of extinction of benthic foraminifera in this century due to ocean acidification, Scientific Reports, 3, 1769, https://doi.org/10.1038/srep01769, 2013.

Wefer, G.: Umwelt, Produktion und Sedimentation benthischer Foraminiferen in der westlichen Ostsee, Reports Sonderforschungsbereich 95 Wechselwirkung Meer - Meeresboden, 14, 1-103, 1976.

Weinmann, A. E. and Goldstein, S. T.: Changing structure of benthic foraminiferal communities: Implications from experimentally grown assemblages of coastal Georgia and Florida, U.S.A., Mar. Ecol., 37, 891-906, 2016.

Weinmann, A. E. and Goldstein, S. T.: Landward directed dispersal of benthic foraminiferal propagules at two shallow-water sites in the Doboy Sound area (Georgia, U.S.A.), J. Foramin. Res., 47, 325-336, 2017.

Wolfram, C.: Die Vegetation des Bottsandes, Mitteilungen der Arbeitsgemeinschaft Geobotanik in Schleswig-Holstein und Hamburg, 51, 1-111, 1996. 